\title{
LANDSLIDE SUSCEPTIBILITY ASSESSMENT IN ALMAS BASIN BY MEANS OF THE FREQUENCY RATE AND GIS TECHNIQUES
}

\author{
Ioan-Aurel IRIMUȘ, ${ }^{I}$ Sanda ROȘCA ${ }^{1}$, Mădălina-Ioana RUS $S^{1}$, \\ Flavia Luana MARIAN', Ștefan BILAȘCO ${ }^{1,2}$
}

DOI: 10.21163/GT_2017.122.09

\begin{abstract}
:
Landslides alongside the erosion are part of the geomorphological processes, specific of Romanian territory, that require agricultural land management issues and processes that lead to increased risk and damage on the population, housing and transport infrastructure. Almaș hydrographic basin, situated in North-West side of Romania, in Almaş - Agrij Depression, is strongly affected by landslides. The purpose of this study is to assess the landslide susceptibility by using the calculation pattern of landslide frequency rate and of the susceptibility index, by means of GIS techniques. Therefore, four groups of landslide susceptibility have been identified: very low, low, moderated and high. The results indicate that $60,36 \%$ of the study area is moderately and highly susceptible to landslides. Emphasis was placed in this study both on identifying spatial susceptibility to landslides, but also on the analysis of causal and releaser factors and on the individual and cumulated influence on the apparition probability so needed in order to make predictions. In order to validate the obtained results, the area under the ROC curve was calculated, whose value of 0.895 indicates the degree of representativeness of the model for the analyzed territory.
\end{abstract}

Key-words: Landslide, Frequency rate, AUROC, GIS modelling.

\section{INTRODUCTION}

Landslide represents a geomorphological process that induces economic losses and negative environmental changes (Irimus,, 2000). Analysing the morphology, morphometry and lithology of Almaş hydrographic basin, it seems that this area is exposed to geomorphological processes, especially to landslides. Consequently, we considered appropriate an assessment study that describes the relation between the frequency and the distribution of landslides and of the highly influencing factors, by implementing the calculation model of the frequency rate of landslides (Fr) and of the susceptibility index (LSI), by means of GIS techniques.

Achieving susceptibility to landslides involves both qualitative and quantitative approaches (Soeters \& van Westen, 1996; Atkinson \& Massari, 1998; Carrara et al, 1995, 1999; Guzzetti et al., 1999; Ayalew \& Yamagishi, 2005; Coe et al., 2004; Sarkar \& Kanungo, 2004; Magliulo, 2008; Zềzere et al., 2004; Bai et al, 2009; Dominiguez Cuesta et al., 2010; Shi-Bio et al, 2010; Sadiki et al, 2011; Costanzo et al., 2012; Cuesta et al., 2010).

\footnotetext{
1"Babeş-Bolyai" University, Faculty of Geography, 400006 Cluj-Napoca, Romania, aurel.irimus@ubbcuj.ro,sanda.rosca@.ubbcluj.ro,luana.magut@gmail.com, rus_madalyna@yahoo.com,stefan.bilasco@ubbcluj.ro

${ }^{2}$ Romanian Academy, Cluj-Napoca Subsidiary Geography Section, 400015, Cluj-Napoca, Romania
} 
As for the Romanian speciality literature, the works on landslide susceptibility assessment have been various: Radoane \& Radoane, 1997; Balteanu et al., 2010; Bilasco et al., 2011; Constantin et al., 2011; Grozavu et al., 2012; Nicorici et. al., 2012; Arghius et. al., 2013; Măgut, 2013; Jurchescu, 2013; Petrea et. al., 2014; Năsui \& Petreuş, 2014; Vâtcă et al., 2014; Marian et al. 2015; Moldovan et al., 2015; Roşca et al., 2015a,b, Colniţă et al., 2016; Roşca, 2016. The landslide susceptibility notion has been explicitly underlined by Brabb, 1984, \& Arghius, 2013, as it follows: "landslide susceptibility is the possibility that a landslide occurs in an area due to local relief conditions".

\section{STUDY AREA, DATA AND METHODS}

Almas Basin, situated in the North-West side of the country, in the marginal unit of Transylvanian Depression, is the transition path between Somes Plateau platform and Meses Mountains Orogene (Fig. 1). Due to the low altitude and to the considerable widening of the valley in middle and lower course of Almas and Agrij rivers, as well as to certain similarities in what concerns the landscape of the hydrographic network, climatic conditions, geological structure, slope processes, soils and vegetations, geographical literature usually includes the two hydrographic basins in a subunit of Transylvanian Subcarpathian area called Almas-Agrij Depression. It is a differential erosion depression, situated at the crossroad of Somes Plateau and Meses Crest (Rosu, 1973).

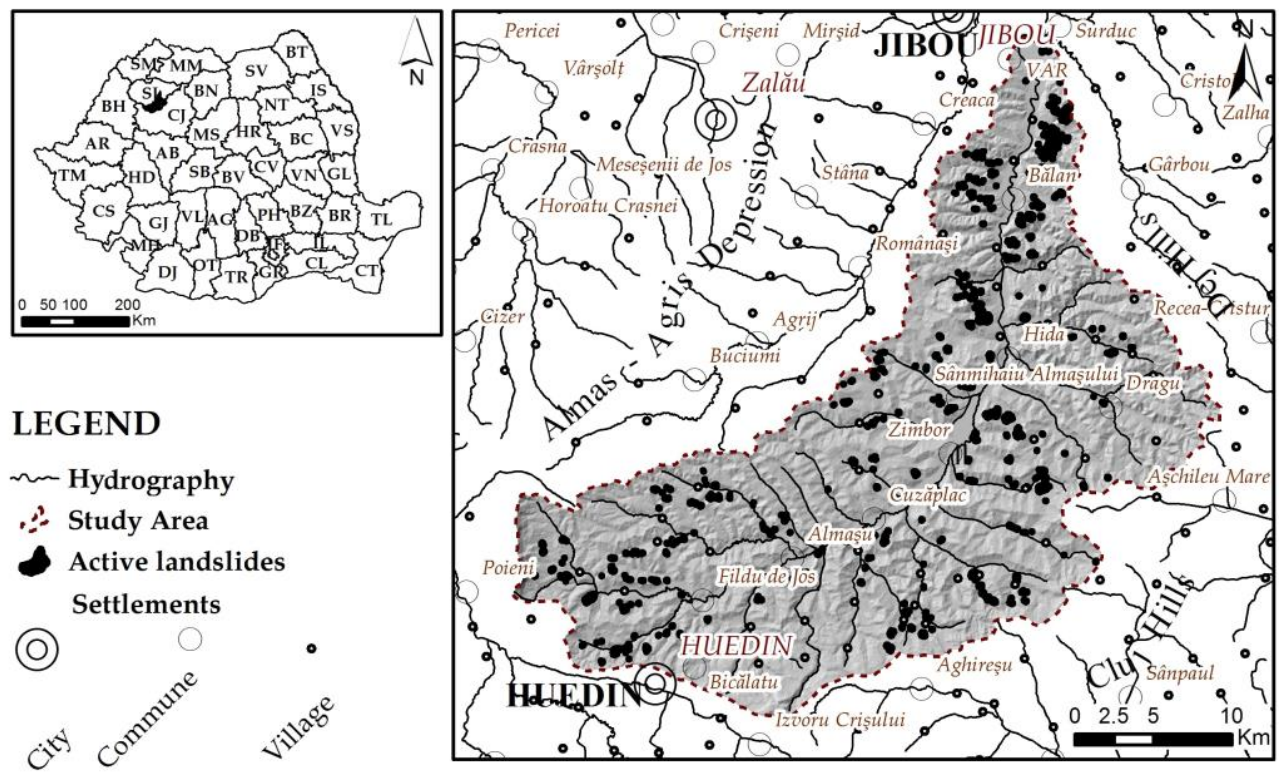

Fig. 1 Location of the study area.

In order to identify landslides susceptibility on the rate of frequency of their related classes of causal and releaser factors, it was necessary to use a database that includes both primary data derived or modelled using GIS technology that offer tools such as statistics analysis and identification of spatial relationship of dependency between the involved factors (Table 1). The elaboration of the landslides susceptibility map focused on the identification 
of the areas affected by such processes, as well as on the elaboration of the inventory map and on the selection of those control factors that might reflect as much as possible the preconditions of landslides triggering. Therefore, while elaborating the landslides susceptibility map, we chose to use the following independent variables: slope, slope orientation, lithology, hypsometry, fragmentation density and land use (Fig. 2).

Database structure

Table 1

\begin{tabular}{|l|l|l|l|l|l|}
\hline Name & Type & Structure & Attribute & Origin & Scale \\
\hline Level curves & Vector & Line & Altitude & Primary & $1: 25000$ \\
\hline Hydrography & Vector & Line & Length & Primary & $1: 25000$ \\
\hline Landslides & Vector & Polygon & Surface & Primary & $1: 25000$ \\
\hline Watershed & Vector & Polygon & - & Primary & $1: 25000$ \\
\hline DEM ( Elevation) & Raster & Grid & Elevation & Shaped & $25 \mathrm{~m}$ \\
\hline Slope & Raster & Grid & Slope (degrees) & $\begin{array}{l}\text { Derived/ } \\
\text { Secondary }\end{array}$ & $25 \mathrm{~m}$ \\
\hline Slope orientation & Raster & Grid & $\begin{array}{l}\text { Orientation } \\
\text { degree }\end{array}$ & $\begin{array}{l}\text { Derived/ } \\
\text { Secondary }\end{array}$ & $25 \mathrm{~m}$ \\
\hline $\begin{array}{l}\text { Fragmentation } \\
\text { density }\end{array}$ & Raster & Grid & Km/km ${ }^{2}$ & Shaped & $25 \mathrm{~m}$ \\
\hline Geology & Vector & Polygon & Lithology & Primary & $1: 200000$ \\
\hline Land use & Vector & Polygon & Type of use & Primary & CLC2006 \\
\hline Susceptibility map & Raster & Grid & Classes & Shaped & $25 \mathrm{~m}$ \\
\hline
\end{tabular}

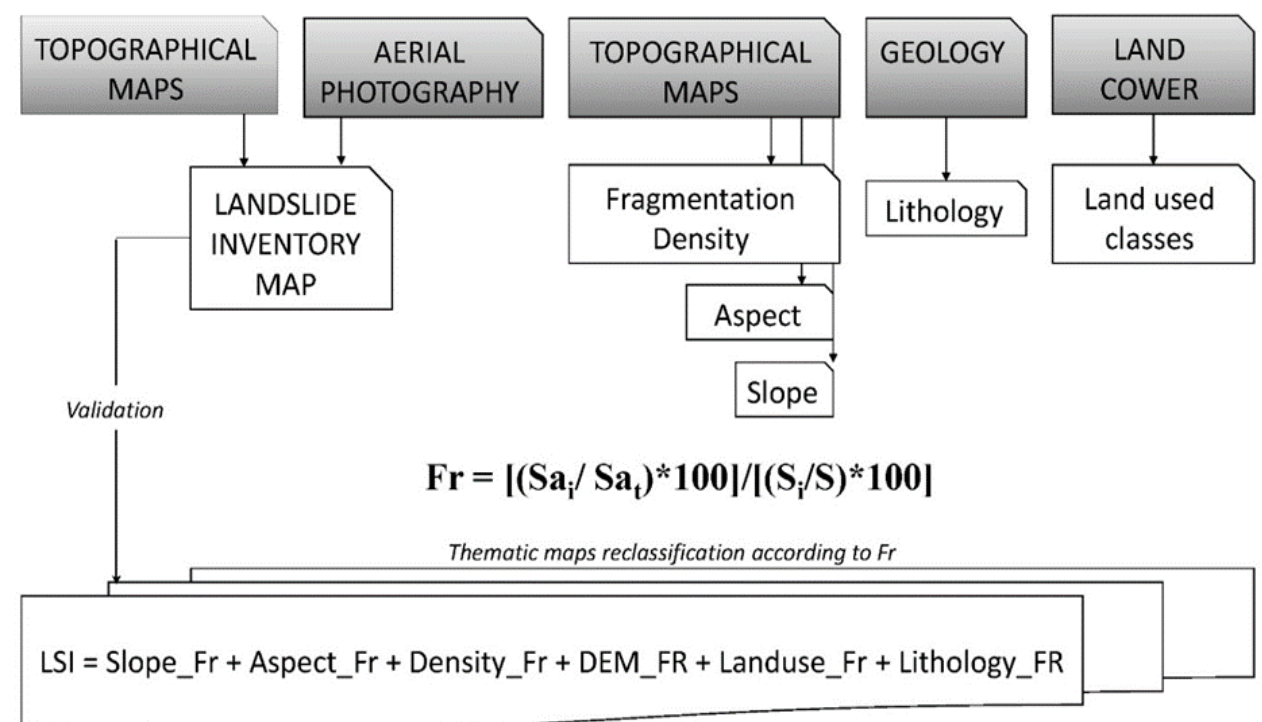

Fig. 2 Stages to elaborate the way to determine the landscape susceptibility by means of GIS techniques. (where: LSI - Landslide Susceptibility Index; Slope_Fr - Slope Frequency; Aspect_Fr Aspect Frequency ; Density_Fr-Density of Fragmentation Frequency; DEM_FR - Digital Elevation Model Frequency; Landuse_Fr-Landuse Frequency; Lithology_FR-Lithology Frequency). 


\subsection{Landslides inventory}

The first step taken in elaborating the study was to draft landslide inventory map for Almaș hydrographic basin. The elaboration of the map was possible by means of topographical maps 1: 25 000, aerial photos and research on the site. Consequently, a number of 198 areas featuring landslides have been identified.

\subsection{Control factors}

Landslides are the result of the collaboration of certain triggering factors, therefore it is essential to identify them, thus complying with the features of the study area.

The elaboration of the digital elevation model (DEM) consisted in digitizing the level curves on topographical maps 1: 25000 by means of ArcMap 10.1 application, as well as of 3D Analyst module that allowed to apply the triangulation methods, by interpolating the values (altitudes) previously assigned to each level curve in the attribute table. Based on the resulted DEM the hypsometric map has been elaborated, according to the following requests: "the quantitative itself nature of hypsometric maps is closely linked to the nature of qualitative item, thus ensuring the links and correspondences that should exist with other geomorphological maps and, in the same time, allowing theoretical and fundamental interpretations, fully consistent with the reality on the site" (Irimuş, 1997).

Based on the DEM resulted (using a $25 \times 25 \mathrm{~m}$ ) resolution, it was possible to generate a series of derived (secondary) maps: slope, slope orientation. The fragmentation density map (drainage density) was calculated and shaped by means of GIS soft functions, based on the classical method (determination of the total length of the hydrographic network to $1 \mathrm{~km} 2$ surface).

The land use analysis was performed according to CORINE Land Cover edition from 2006. The date of reference for CORINE Land Cover inventory is 1990, followed by updates in 2000 and 2006. CORINE Land Cover holds a database consisting in 44 classes of fields overlay. Among these, 11 classes have been identified in Almaş hydrographic basin. In order to easily analyse this model, we performed a reclassification, therefore 8 categories of use are to be considered. The cartographic support was made by means of ArcGIS programme. (Rus \& Irimuş, 2015).

The digitisation of geological map 1: 200 000, Jibou Sheet led to lithology. The following formations existing in Almas basin have been identified and used as database (9 classes): sandstone, clay marl $(4,67 \%)$, clays, sands, sandstone, bituminous marl $(27,78 \%)$, marl, coal shale, limestone $(1,47 \%)$, limestone, marl, gypsum, sandstone, clays $(6,93 \%)$, dacite $(0,15 \%)$, conglomerates, sands, sandstone, marl $(25,38 \%)$, sands, gravels $(11,91 \%)$, conglomerates, sandstone, marl clays (Hida strata) (22,59\%), micaschists, paragneiss $(0,39 \%)$. The class represented by clays, sands, sandstone, bituminous marl, Oligocen deposit (rupelian) is mostly spread $(25,78 \%)$. The local influence of the lithology on geomorphological process occurrence it is an important step witch can be harder evaluate in a detailed studies (Cristea, 2015).

It is most represented in Almaș upper basin and fills a quite continuous surface on the left slope, to the downstream of Cuzaplac locality. The subsequent class (as for the percentage from the total surface of the basin) consists in conglomerates, sands, sandstone, marl, Oligocene 
deposits (Chattian-Aguitanian) (25,38\%), representing a quite similar development compared to Almas course, in the middle basin. Still, such deposits are also present in Almas spill area.

The following step was to determine classes for each factor, and to calculate the surface and the percentage of each class, as reported to the surface of the entire calculation area (Table 2). The shape of the relation between landslides and control factors was possible by means of the calculation method of the frequency rate (Fr). This model has also been applied by Lee \& Min, 2001; Lee \& Sambath, 2006, Lee \& Pradhan, 2007; Jadda et al., 2009; Arghius et al., 2013.

The frequency rate is the report between the landslides surface of each class as percentage of all landslides surface and the class surface as percentage of all study area.

The relations between landslides and generating factors have been identified and quantified by means of the generated database, subsequently required to implement the calculation formula for the frequency rate (Fr). As for this study, we chose the landslide frequency rate method as quantitative method. Such method has been successfully applied by Lee \& Min, 2001; Dai \& Lee, 2002; Lee \& Pradhan, 2007; Choi et. al., 2012; Arghiuș et. al., 2013.

The calculation of the frequency rate required the determination of landslides surface corresponding to each class, as well as of landslides percentage for each class, from the entire surface of landslides in Almas hydrographic basin $\left(26,31 \mathrm{~km}^{2}\right)$. In order to determine the landslides frequency rate (FR), the following formula (1) was applied:

$$
\operatorname{Fr}=[(\mathrm{Sai} / \mathrm{Sat}) * 100] /[(\mathrm{Si} / \mathrm{S}) * 100]
$$

where:

Fr- frequency rate

Sai- landslide surface for class $i$ of factor $\left(\mathrm{km}^{2}\right)$

Sat- landslides total surface $\left(\mathrm{km}^{2}\right)$

$\mathrm{Si}$ - surface of class $i\left(\mathrm{~km}^{2}\right)$

$\mathrm{S}$ - surface of basin, study area $\left(\mathrm{km}^{2}\right)$.

For value 1 of the frequency report, the class of the factor features a landslide density proportional to the size of the class reported to the study area. If Fr is larger than 1, it means that there is a high correlation between landslides and class of the control factor. If $\mathrm{Fr}$ is less than 1, it means that there is a low correlation between the two variables (Lee \& Sambath, 2006). Following the calculation of the frequency rate index, each thematic map has been reclassified, considering the value of the new generated index (Fr).

The landslides susceptibility index (LSI) was calculated as the total value of the frequency report of each factor (Lee \& Min, 2001; Arghius et.al. 2013), by means of the equation (2):

$$
\mathrm{LSI}=\Sigma \mathrm{Fr}
$$

where:

LSI - landslides susceptibility index

Fr- frequency rate 


\section{RESULTS AND DISCUSSION}

The elaboration of the Inventory map of landslides was the first result of the use of such model. A number of 198 landslides on a $26,31 \mathrm{~km}^{2}$ surface has been identified, meaning 3,19\% of the total surface of Almas hydrographic basin $\left(814,5 \mathrm{~km}^{2}\right)$.

By means of GIS soft techniques, it was possible to correlate landslides and the classes of each factor or independent variable taken into account (Table 2). The landslides surface for each factor class and the landslides surface for each class have been determined as percentage of the entire surface of landslides. These values are necessary in determining the Frequency rate (Fig. 3).

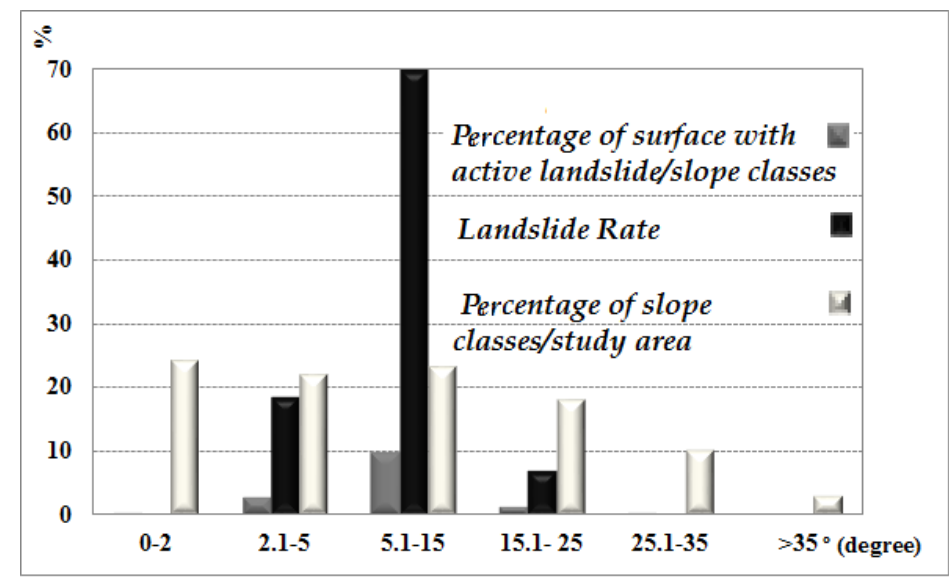

Fig. 3 Correlation between slope classes and landslides percentage.

It is noticed that as reported to the slope classes, the highest percentage of landslides from the entire surface of slopes at the basin level is on slopes featuring an inclination degree between $5.1^{\circ}-15^{\circ}$, meaning $69,7 \%$ and $2,1^{\circ}-5^{\circ}(18,37 \%)$. As for the slopes featuring inclination degree larger than $35^{\circ}$, no landslide has been identified.

As for the slope orientation, it was noticed that most landslides occur on northern, north-eastern and eastern slopes, namely shadowed and half-shadowed slopes, where soil humidity continues on a longer period, due to the caloric regime lower than on the sunny and half-sunny slopes.

Analysing the correspondence between landslides and hypsometry underlined the occurrence of landslides mostly between $301-400 \mathrm{~m}$, representing a percentage of all landslides in the basin of $45,2 \%$ on a $11,89 \mathrm{~km}^{2}$ surface, namely $4,73 \%$ of the altimetric class surface.

The definition of landslides surface for each class as percentage of the entire landslides surface, as well as of the class surface as percentage of the entire study area allowed applying the equation (2) and the calculation of the frequency rate (Fr). The results are detailed in Table 2.

Analysing the frequency rate of active landslides that manifests at the Almăjului basin, the highest values for north slopes, an incline of the land located in 0,5-1 degrees with an altitude between 300-400 m which are predominantly used as pastures (Fig .4), observing in this case the negative effect of overgrazing on the reactivation and the dynamics of landslides. 
Relation between landscapes and control factors

\begin{tabular}{|c|c|c|c|c|c|c|}
\hline Variables & Classes & $\begin{array}{c}\text { Surface } \\
\left(\mathbf{k m}^{2}\right)\end{array}$ & $\begin{array}{c}\text { Class \% from } \\
\text { the basin }\end{array}$ & $\begin{array}{c}\text { Landslide } \\
\left(\mathbf{k m}^{2}\right)\end{array}$ & $\begin{array}{l}\% \text { of total } \\
\text { landslides }\end{array}$ & $\mathbf{F}_{\mathbf{r}}$ \\
\hline \multirow{6}{*}{$\begin{array}{l}\frac{\partial}{a} \\
\frac{a}{a}\end{array}$} & $0-2$ & 193,00 & 24 & 0,01 & 0,03 & 0,001 \\
\hline & $2.1-5$ & 178,22 & 22 & 4,833 & 18,37 & 0,83 \\
\hline & $5.1-15$ & 189,85 & 23 & 18,344 & 69,72 & 3,03 \\
\hline & $15.1-25$ & 142,43 & 18 & 1,795 & 6,82 & 0,38 \\
\hline & $25.1-35$ & 83,00 & 10 & 0,018 & 0,07 & 0,01 \\
\hline & $>35$ & 28,00 & 3 & 0 & 0 & 0,00 \\
\hline \multirow{8}{*}{ 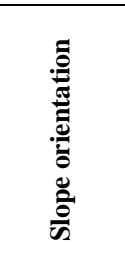 } & North & 136,45 & 16,75 & 6,51 & 24,74 & 2,92 \\
\hline & North-East & 134,46 & 16,51 & 4,54 & 17,26 & 1,05 \\
\hline & East & 99,07 & 12,16 & 3,98 & 15,14 & 1,24 \\
\hline & South-East & 79,27 & 9,73 & 2,72 & 10,35 & 1,06 \\
\hline & South & 89,99 & 11,05 & 2,61 & 9,93 & 0,90 \\
\hline & South-West & 95,01 & 11,66 & 2,58 & 9,80 & 0,84 \\
\hline & West & 79,10 & 9,71 & 1,39 & 5,30 & 0,55 \\
\hline & North-West & 100,81 & 12,38 & 1,73 & 6,56 & 0,53 \\
\hline \multirow{5}{*}{ 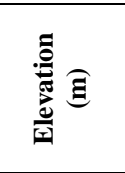 } & $178-300$ & 134,8 & 17 & 6,67 & 25,4 & 1,49 \\
\hline & $301-400$ & 251,8 & 31 & 11,89 & 45,2 & 1,46 \\
\hline & $401-500$ & 269,9 & 33 & 5,76 & 21,9 & 0,66 \\
\hline & $501-600$ & 130,6 & 16 & 1,45 & 5,5 & 0,34 \\
\hline & $>600$ & 27,1 & 3 & 0,42 & 1,6 & 0,53 \\
\hline \multirow{6}{*}{ 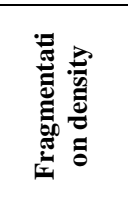 } & $0-0,5$ & 195,1 & 25 & 10,16 & 38,62 & 1,54 \\
\hline & $0,5-1$ & 191,6 & 24 & 10,32 & 39,22 & 1,63 \\
\hline & $1-1,5$ & 191,2 & 23,5 & 4,67 & 17,75 & 0,76 \\
\hline & $1,5-2$ & 154,6 & 17,5 & 0,08 & 0,30 & 0,02 \\
\hline & $2-2,5$ & 64,5 & 8 & 0,97 & 3,69 & 0,46 \\
\hline & $>2,5$ & 17,6 & 2 & 0 & 0,00 & 0,00 \\
\hline \multirow{7}{*}{ 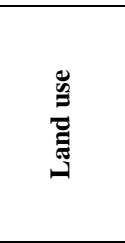 } & Arable & 250,00 & 30,69 & 14,95 & 56,82 & 1,85 \\
\hline & Built-up areas & 42,77 & 5,25 & 0,50 & 1,90 & 0,36 \\
\hline & Orchards & 4,70 & 0,58 & 0,16 & 0,61 & 1,05 \\
\hline & Forest bushes & 21,00 & 2,58 & 0,09 & 0,34 & 0,13 \\
\hline & Hardwoods & 327,69 & 40,23 & 1,70 & 6,46 & 0,16 \\
\hline & Pastures & 159,37 & 19,57 & 5,94 & 22,58 & 1,15 \\
\hline & Vineyards & 8,00 & 0,98 & 0,5 & 0,19 & 0,19 \\
\hline \multirow{9}{*}{ 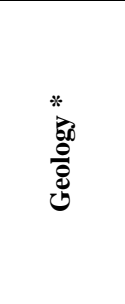 } & 1 & 38 & 4,67 & 2,8 & 10,64 & 2,28 \\
\hline & 2 & 210 & 25,78 & 3,24 & 12,31 & 0,48 \\
\hline & 3 & 12 & 1,47 & 0,02 & 0,08 & 0,05 \\
\hline & 4 & 56,42 & 6,93 & 1,17 & 4,45 & 0,64 \\
\hline & 5 & 1,25 & 0,15 & 0,07 & 0,27 & 0,01 \\
\hline & 6 & 206,74 & 25,38 & 7,95 & 30,22 & 1,19 \\
\hline & 7 & 97 & 11,91 & 1,28 & 4,87 & 0,41 \\
\hline & 8 & 184 & 22,59 & 5,95 & 22,61 & 1,00 \\
\hline & 9 & 3,14 & 0,39 & 0,06 & 0,23 & 0,59 \\
\hline
\end{tabular}

*1 Sandstone, marl clay; 2 Clays, sands, sandstone, bituminous marl; 3 Marl, coal schist, limestone; 4 Limestone, marl, gypsum, sandstone, clays; 5 Dacite; 6 Conglomerates, sands, sandstone, marl; 7 Sand, gravels; 8 Conglomerates, sandstone, marl clays (Hida strata); 9 Micaschists, paragneiss.

The lowest values of the frequency rate $(<1)$ feature the following classes: $0^{\circ}-2^{\circ}$ $(0,18), 15^{\circ}-25^{\circ}(0,38)$ and $25^{\circ}-35^{\circ}(0.01)$, with low probability for landslides to occur (Figures 6, 7). 


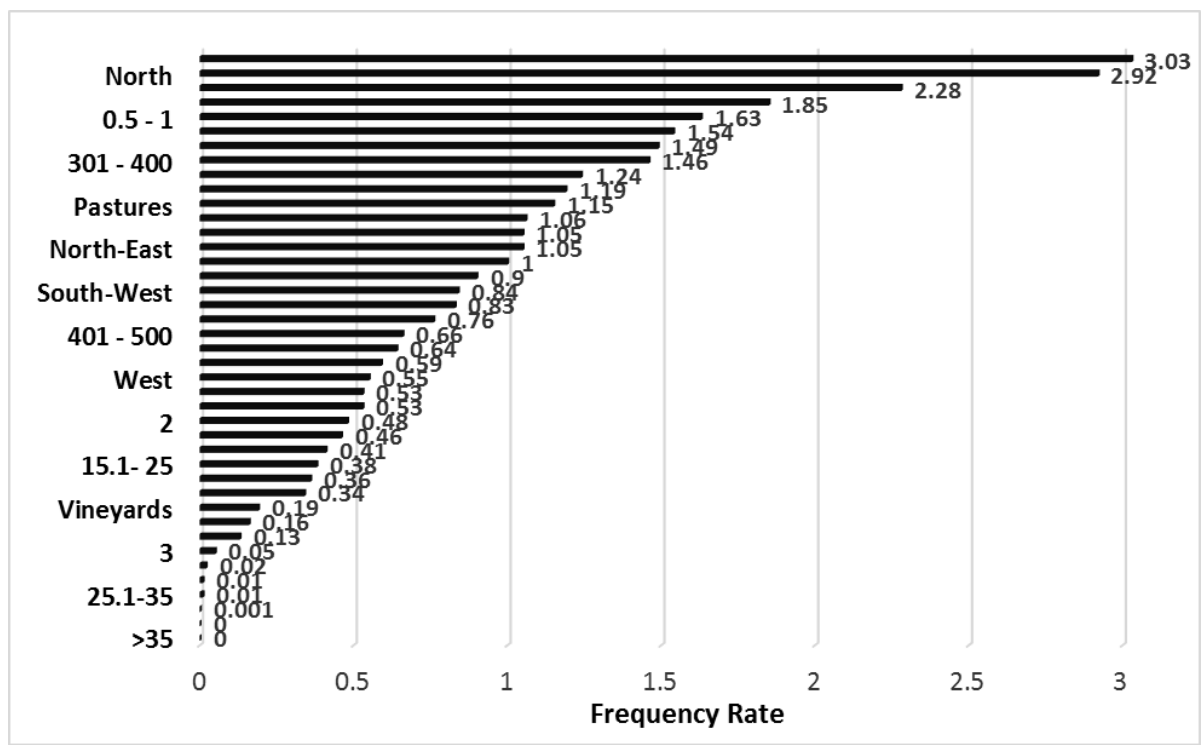

Fig. 4 The frequency rate variation.

Depending on the slope inclination degree, we may state that $23 \%$ of the basin surface (featuring an inclination degree between $5,1^{\circ}-15^{\circ}$ ) is liable to landslides, while $77 \%$ of the basin features low values of landslide susceptibility, from the point of view of the slope degree. As for the slope orientation, the frequency rate of landslides is greater than 1 in the following situations: Northern slopes $(\mathrm{Fr}=2,92)$, North-Eastern slopes $(\mathrm{Fr}=1,05)$, Eastern slopes $(\mathrm{Fr}=1,25)$ and South-Eastern slopes $(\mathrm{Fr}=1,06)$, thus featuring a close correlation between such slopes and landslides, as the slopes are liable to landslides. On the other side, Southern, South-Western, Western and North-Western slopes feature values lower than 1.

The frequency rate values in case of fragmentation density are greater than 1 in case of the following intervals: $0-0,5 \mathrm{~km} / \mathrm{km}^{2}(\mathrm{Fr}=1,54)$ and $0,5-1 \mathrm{~km} / \mathrm{km}^{2}(\mathrm{Fr}=1,63)$, while the rest of density classes feature Fr lower than 1, meaning a lower susceptibility to landslides. The frequency rate exceeds value 1 in case of altimetric intervals between 178$300 \mathrm{~m}$ and $301-400 \mathrm{~m}$, which means that from the altimetric point of view, $48 \%$ of Almaș basin surface is liable to landslides.

In relation to lithology formations, the landslide frequency rate features values greater than 1, in case of the following lithology classes: sandstone, marl clays (MioceneBadenian), conglomerates, sands, sandstone, marl (Oligocene-Chattian-Aquitanian), conglomerates, sandstone, marl clays (Miocene-Helvetian), all featuring a 52\% percentage of the study area surface. The calculation of the frequency rate in case of land use revealed a high susceptibility in case of arable lands $(\mathrm{Fr}=1,85)$ and of pastures $(\mathrm{Fr}=1,15)$.

In order to determine the landslide susceptibility index (LSI), the amount of factor reclassified according to the value of the frequency rate index (Fr) has been generated by means of Raster Calculator (ArcMap 10.1 application), using the spatial analysis formula (3):

$$
\begin{aligned}
& \text { LSI="SLOPE_FR"+"ASPECT_FR"+"DENSITY_FR"+"DEM_FR"+ } \\
& \text { "LANDUSE_FR"+"LITHOLOGY_FR" }
\end{aligned}
$$


The values obtained by generating the susceptibility map have been divided into 4 classes (according to Barredo, 2000, Arghius, 2013) (Table 3).

In case of Almas hydrographic basin, the LSI index (landslide susceptibility index) features a minimal value of 7,16, a maximum value of de 21,8 and a moderated value of 16 , reported to a 2,41 deviation standard. The generated susceptibility map, based on the susceptibility index, revealed the following 4 susceptibility classes:

- Very low (7,1-13): on a $81,63 \mathrm{~km}^{2}$ surface $(10,03 \%$ of basin surface);

- Low (13-15): corresponding to a 225, $43 \mathrm{~km}^{2}$ surface, while in absolute value, 27,69 $\%$ of the study area surface;

- Moderated (15-18): class featuring the largest share $\left(37,99 \%\right.$, on a $309,24 \mathrm{~km}^{2}$ surface);

- High (18-21.79): 182, $11 \mathrm{~km}^{2}$ engaged surface, featuring a percentage of 22,37\%.

Percentage of susceptibility classes

Table 3

\begin{tabular}{|c|c|c|c|}
\hline Susceptibility classes & Fr Values & Surface $\left.\mathbf{( k m}^{\mathbf{2}}\right)$ & Percentage (\%) \\
\hline Very low & $7,1-13$ & 81,63 & 10,03 \\
\hline Low & $13-15$ & 225,43 & 27,69 \\
\hline Moderated & $15-18$ & 309,24 & 37,99 \\
\hline High & $>18$ & 182,11 & 22,37 \\
\hline
\end{tabular}

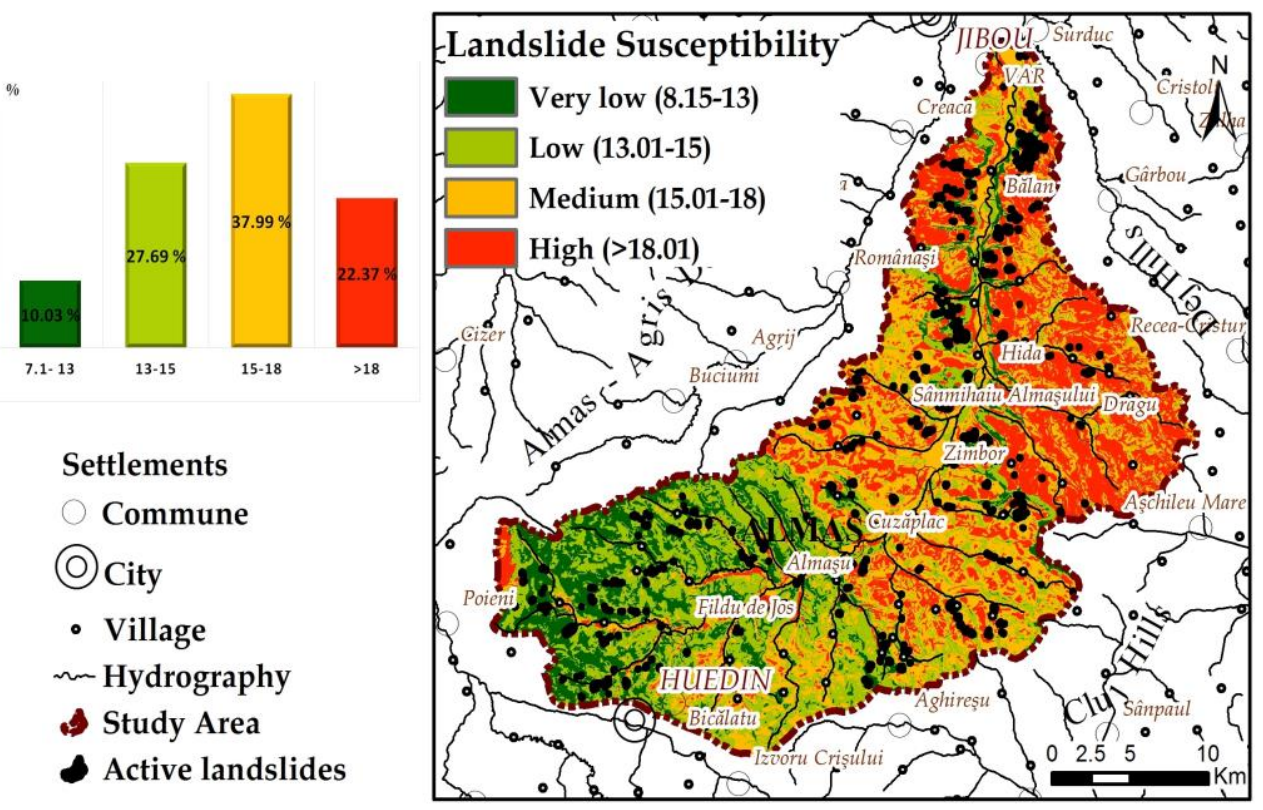

Fig. 5 Landslide susceptibility classes in Almas hydrographic basin calculated according to the frequency rate $(\mathrm{Fr})$. 


\section{CONCLUSIONS}

The implementation of the calculation model of landslide susceptibility, by means of frequency rate and GIS techniques revealed the following results:

- $\quad 37.73 \%$ of Almas basin features very low and low susceptibility values (between 7 and 13) and are typical mainly to the upper basin, as well as to Almas depression and most of its affluent.

- $\quad 37,99 \%$ of the area features landslide frequency rate values between 15-18, a moderate susceptibility to landslides (middle and lower basin, piedmont Meseș area).

The highest susceptibility values feature the $182,11 \mathrm{~km}^{2}$ area $(22,37 \%)$. The areas included in this susceptibility class are the middle and the lower basin that overlap the Oligocene geological area (Chattian-Aquitanian) and especially Miocene areas (Helvetian and Burdigalian).

In order to identify the degree of predictability of the applied model for frequencydependent analysed territory landslides, the value of the curve aria was identified (Are Under the Receiver Operating Characteristic curve). This validation tool was used in similar studies by Van Den Eeckhaut et al., 2009; Pourghasemi et al. 2012; Petrea et al., 2014, Rosca, 2015a, b etc.

In a previous phase the rate of true positive was identified, which shows the model sensitivity, so the number of pixels classified in higher classes susceptibility, on which level are identified spatial active landslides and false positive rates, hence of the model specificity for the pixels characterized by high values of the probability of landslides occurrence, on which level are not existing active landslides at the moment (Fig. 6).

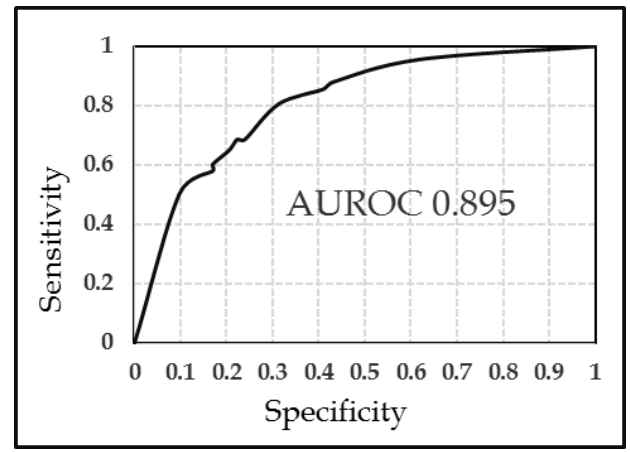

Fig. 6 The model validation using AUROC.

The elaboration of such model is truly practical, for two reasons. First, it identifies and defines the areas liable to landslides, considering the local climatic conditions and the triggering factors. Secondly, this study is a preliminary step for future analysis, measurement and research, more detailed and more comprehensive in terms of landslide dynamics in Almas Basin. Therefore, this study requires a closely collaboration to geologists and geotechnical staff.

\section{ACKNOWLEDGMENT}

All the authors have equal contributions on this paper. 


\section{R E F E R E N C E S}

Arghius, Corina, Arghius, V., Ozunu, A., Muntean, L. \& Mihaiescu, R. (2013) Landslide susceptibility assessment in Codrului Hills (North-Western part of Romania), Carpathian Journal of Earth and Environmental Sciences, 8 (3), 137-144.

Atkinson, P.M., Massari, R. (1998) Generalized linear modelling of susceptibility to landsliding in the central Apennines, Italy, Computers and Geosciences 24, 373-385.

Ayalew, L., Yamagishi, H. (2005) The application of GIS-based logistic regression for landslide susceptibility mapping in the Kakuda-Yahiko Mountains, Central Japan, Geomorphology 65, $15-31$.

Bai, S.B., Wang, J., Lü, G.N., Zhou, P.G., Hou, S.S., Xu, S.N. (2009) GIS-based and data driven bivariate landslide-susceptibility mapping in the Three Gorges Area, China, Pedosphere 19, 14 20.

Bălteanu D, Chendeş V, Sima M, Enciu P. (2010) A country-wide spatial assessment of landslide susceptibility in Romania, Geomorphology, 124, 102-112.

Bilasco, St., Horvath, Cs., Rosian, Gh., Filip S. \& Keller, I., E. (2011) Statistical model using GIS for the assessment of landslide susceptibility. Case-study: the Somes plateau, Romanian Journal of Geography, Romanian Academy Publisher, Bucharest, 2, 91-111.

Brabb, E.E. (1984) Innovative approaches to landslide hazard and risk mapping. Proceedings, 4th International Symposium on Landslides, 1, 307-324. Canadian Geotechnical Society, Toronto.

Carrara, A., Guzzetti, F., Cardinali, M., Reichenbach, P. (1999) Use of GIS Technology in the Prediction and Monitoring of Landslide Hazard. Natural hazards, 20 (2), 117-135.

Carrara, A., Guzzetty, F. (1995) Geomorphical Information Systems in Assessing Natural Hazards. Kliwer Academic Publisher, Dordrecht, Holland.

Coe, J.A., Godt, J.W., Baum, R.L., Bucknam, R.C., Michael, J.A. (2004) Landslide Susceptibility from topography in Guatemala. In: Lacerda WA, Erlich, M., Fontoura, S.A.B., and Sayao, A.S.F., eds., Landslides, evaluation \& stabilization. Proceedings of the 9th international Symposium on Landslides, Rio de Janeiro 1:69-79.

Colniță, D., Păcurar, I., Roşca, S., Bilaşco, Şt., Păcurar, H., Boț, A.I., Dîrja, M. (2016) Spatial Analysis GIS Model for Identifying the Risk Induced by Landslides. A Case Study: A.T.U. of Sieu, Bulletin UASVM series Agriculture 73 (2), 198-207.

Constantin, M. (2011) Landslide susceptibility assessment using the bi-variate statistical analysis and the index of entropy in the Sibiciu Basin (Romania), Environ. Earth Sci., 63, 397-406.

Costanzo D., Bhacon, J., Conoscenti, Ch., Irigaray, C., Rotigliano, E. (2012) Forward logistic regression for earth flow landslide susceptibility assessment in the Platani river basin (southern Sicily, Italy), Landslides, 11, 639653.

Cristea A-I. (2015) Spatial Analysis of Channel Steepness in a Tectonically Active Region: Putna River Catchment (South-Eastern Carpathians). Geographia Technica, 10 (1): 19-27.

Cuesta, M., Jiménez Sánchez, M., Colubi, A., y González Rodríguez, G. (2010) Modelling shallow landslide susceptibility: a new approach in logistic regression by using favourability assessment, in Earth and Science, 99, 661674.

Dai, F.C., Lee, C.F. (2002) Landslide characteristics and slope instability modelling using GIS Lantau Island, Hong Kong, Geomorphology 42, 213- 238

Domıniguez Cuesta MJ, Jimenez Sanchez M, Colubi A, Gonzalez Rodrıguez G. (2010) Modelling shallow landslide susceptibility: a new approach in logistic regression by using favourability assessment, International Journal of Earth Sciences INT J EARTH SCI, 99 (3), 661674.

Grozavu, A., Mărgărint, M.C., Patriche, C.V. (2012) Landslide susceptibility assessment in the Brăiești-Sinești sector of Iași Cuesta, Carpath. J. Earth Env., 7, p. 39-46.

Guzzetti, F., Carrara, A., Cardinali, M., Reichenbach, P. (1999) Landslide hazard evaluation: a review of current techniques and their application in a multi-scale study, central Italy, Geomorphology, 31, 181-216. 
Irimuș, I.A. (1997) Geomorphological Cartography (in Romanian) Focul Viu Print House, Cluj Napoca, $111 \mathrm{pp}$.

Irimuș, I.A., Vescan, I., Man, T. (2005) Tehnici de cartografiere, monitoring si analiza GIS. Ed.Casa Cartii de Stiinta, Cluj-Napoca, 244 pp.

Jadda, M. (2009) Landslide Susceptibility Evaluation and Factor Analysis. European Journal of Scientific Research 33 (4), 654-668.

Jurchescu, Marta (2013) Hidrogeomorphological Basin Oltet. Study of Applied Geomorphology, PhD Thesys, University of Bucharest (in Romanian).

Lee, Moung-Jin, Park, Inhye. Lee, S. (2015) Forecasting and validation of landslide susceptibility using an integration of frequency ratio and neuro-fuzzy models: a case study of Seorak mountain area in Korea, Environmental Earth Sciences, 74 (1), 413-429.

Lee S, Sambath T. (2006) Landslide susceptibility mapping in the Damrei Romel area, Cambodia using frequency ratio and logistic regression models. Environ Geol 50, 847-855.

Lee, S., Min, K. (2001) Statistical analysis of landslide susceptibility at Youngin, Korea. Environmental Geology, 40, 1095-1113.

Lee, S., Pradhan, B. (2006) Probabilistic landslide hazards and risk mapping on Penang Island, Malaysia. Journal of Earth System Science, 115, 661-672.

Lee S, Choi J, Min K. (2004) Probabilistic landslide hazard mapping using GIS and remote sensing data at Boun, Korea. Intl J Remote Sens., 25, 2037-2052.

Magliulo, P., Antonio Di Lisio, Russo, F. (2008) Comparison of GIS based methodologies for the landslide susceptibility assessment, DOI 10.1007/s10707 0080063 Springer Science Business Media, LLC.

Marian, Flavia, Irimuş, I. A., Zaharia, C., S. (2015) Qualitative Landslide Risk Estimation In The Baia Mare Depression, Romania, Carpathian Journal of Earth and Environmental Sciences, 11 (1), $123-130$.

Măguț, Flavia, Luana (2013) Risk to Landslide in Baia Mare Depression, PhD Thesys, Babes Bolyai University, Cluj Napoca (in Romanian).

Moldovan N., Păcurar I., Bilașco St., Roșca S., Boț A. (2015) The Analysis of Vulnerability to Landslides in Order to Determine the Risk on Farmland. Case Study: Intercommunity Association Area for Development Alba Iulia, Proenviroment, 8, 36-546.

Năsui, D., Petreuş, A. (2014) Landslide Susceptibility Assessment In The Iricău Glacis (Baia Mare City, Romania), Carpathian Journal of Earth and Environmental Sciences, 9 (4), 185-190.

Nicoricic., Grayj.,Imbroane A.M. \& Barbosu M. (2012) GIS susceptibility maps for shallow landslides: a case study in Transylvania Romania. Carpathian Journal of Earth and Environmental Sciences, 7 (2), 83-92.

Petrea, D., Bilaşco, Şt., Roşca, S., Vescan. I., Fodorean, I. (2014) The determination of the Landslide occurence probability by spatial analysis of the Land Morphometric characteristics (case study: The Transylvanian Plateau), Carpathian Journal of Earth and Environmental Sciences., 9, 91110.

Pourghasemi, H. R., Biswajeet Pradhan, Gokceoglu, C., Deylami Moezzi, K. (2012) Landslide Susceptibility Mapping Using a Spatial Multi Criteria Evaluation Model at Haraz Watershed, Iran, in Terrigenous Mass Movements, 23-49, Springer.

Rădoane, Maria, Rădoane, N (2007) Applied Geomorphology, Editura Universităţii, Suceava (in Romanian).

Roşca S., Bilaşco Şt., Petrea D., Fodorean I., Vescan I. \& Filip S. (2015a) Application of landslide hazard scenarios at annual scale in the Niraj River basin (Transylvania Depression, Romania), Natural Hazards, 77, 1573-1592.

Roşca S. (2015b) Niraj Basin. Study of Applied Gepmorphology, Risoprint, Cluj Napoca (in Romanian).

Roşca S., Bilaşco Şt., Petrea D., Vescan I., Fodorean I. (2016) Comparative assessment of landslide susceptibility. Case study: the Niraj river basin (Transylvania depression, Romania), Geomatics Natural Hazards and Risk, 7 (3), 1043-1064. 
Roșu, Al (1973) Physical Geography of Romanian, Ed. RSR., București (in Romanian).

Rus, Madalina, Irimus, I.A. (2015) Soils vulnerability of Catchment Almaş at geomorphologic contemporary processes. Riscuri şi Catastrofe, 16 (1), 33-43.

Sarkar, S., Kanungo, D.P. (2004) An integrated approach for landslide susceptibility mapping using remote sensing and GIS. Photogrammetric Engineering and Remote Sensing, 70(5), 617-625.

Soeters, R., van Westen, C.J. (1996) Slope instability recognition, analysis, and zonation. In: Turner, K.A., Schuster, R.L. (Eds.), Landslides: investigation and mitigation, Transport Research Board Special Report, 247, 129- 177.

Shi-Biao Bai, Jian Wang, Guo-Nian Lü, Ping-Gen Zhou, Sheng-Shan Hou, Su-Ning Xu (2010) GISbased logistic regression for landslide susceptibility mapping of the Zhongxian segment in the Three Gorges area, China. Geomorphology, 115, $23-31$.

Sadiki, A., Faleh, A., Mesrar, H. (2011) Landslide susceptibility modelling using GIS and statical method in the Oued Larbaa basin (Eastern Rif, Morocco). J. Mater. Environ. Sci., 2 (S1), 526531.

Van Den Eeckhaut, M., Reichenbach, P., Guzzetti, F., Rossi, M., Poesen, J. (2009) Combined landslide inventory and susceptibility assessment based on different mapping units: an example from the Flemish Ardennes, Belgium. Nat. Hazards Earth Syst. Sci., 9, 507-521.

Vâtca, A., Irimuș, A., Roșca, S. (2014) Landslide susceptibility in Zalău Municipality. Revista de Geomorfologie, 16, 37-45.

Zêzere J.L., Reis E, Garcia R, Oliveira S, Rodrigues M.L, Vieira G, Ferreira A.B. (2004) Integration of spatial and temporal data for the definition of different landslide hazard scenarios in the Area North of Lisbon (Portugal). Nat. Hazards Earth Syst. Sci., 4, 133-146. 